\title{
Triterpene saponins of Genista ulicina Spach
}

Naima Boutaghane, ${ }^{\mathrm{a}, \mathrm{b}}$ Laurence Voutquenne -Nazabadioko, ${ }^{* a}$ Dominique Harakat, ${ }^{\mathrm{a}}$ Alain Simon $^{\mathrm{c}}$, Zahia Kabouche ${ }^{\mathrm{b}}$

a Institut de Chimie Moléculaire de Reims (ICMR), CNRS UMR 7312, UFR de Pharmacie, BP 1039, 51687 Reims; France.

${ }^{\mathrm{b}}$ Laboratoire d'Obtention des Substances Thérapeutiques, Faculté des Sciences Exactes, Université Mentouri Constantine, Chaabet Ersas Campus, 25000 Constantine, Algeria.

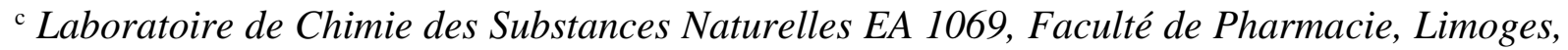
France.

* Corresponding author. Tel.: +33 326918209.

E-mail adress : laurence.nazabadioko@univ-reims.fr (L. Voutquenne-Nazabadioko)

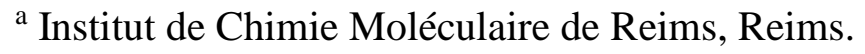

${ }^{\mathrm{b}}$ Laboratoire d'Obtention des Substances Thérapeutiques, Constantine, Algeria.

${ }^{\mathrm{c}}$ Laboratoire de Chimie des Substances Naturelles, Limoges 


\section{Abstract}

From the $n-\mathrm{BuOH}$ extract of the aerial parts of Genista ulicina, six triterpene saponins, 3-O- $\beta$ D-glucopyranosyl-olean-12-ene-3 $\beta, 27,28,30$-tetraol， 3-O- $\beta$-D-glucopyranosyl-olean-12-ene-

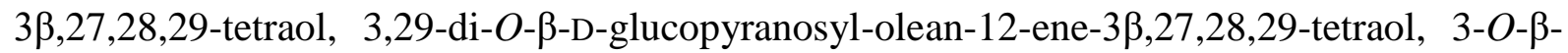
D-glucopyranosyl-olean-12-ene-3 $\beta, 28,29$-triol-27-oic acid, 3-O- $\beta$-D-glucopyranosyl-olean-12ene-3 $\beta, 27,28$-triol-29-oic acid, and 3-O- $\beta$-D-glucopyranosyl-14- $H$-27-nor-olean-12-ene33,28,29-triol, were isolated together with eight seven known triterpene saponins and six flavonoids. Their structures were established mainly by means of spectroscopic methods (1D and 2D-NMR as well as HR-ESI-MS). The $n-\mathrm{BuOH}$ extract, investigated for its antitumor growth inhibition of human colon cancer HT-29 cells, presented no significant activity (IC ( $_{50}>$ $100 \mu \mathrm{g})$. 
Keywords:

Genista ulicina

Fabaceae

Triterpenoid saponins

Cytotoxic activity 


\section{Introduction}

Fabaceae is the second largest family of medicinal plants, containing over 490 medicinal plant species most of which have been used as traditional medicines (Ting et al., 2010). Many genera of this family such as Genista have recently attracted the attention of various authors for their phytochemical and biological properties, particularly antidiabetic (Rauter et al., 2005, 2009), antiinflammatory, antiulcer (Ilarionov, 1979; Rainova et al., 1988) spasmolytic, antioxidant, phytoestrogenic (Luczkiewicz and Glod, 2003; Garritano et al., 2005) and cytotoxic activity against different human cancer cell lines (Rigano et al., 2009, 2010), and effects on the thyroid gland (Korpachov et al., 1995).

The genus Genista (Fabaceae = Leguminosae) consists of 100 species predominantly distributed in the Mediterranean area and in Western Asia (Noccioli et al., 2011). Among these species, 23 grow in Algeria including 11 endemics distributed particularly in the Northern parts of the country (Quezel and Santa, 1963). Previous phytochemical investigations on the Genista genus indicated the presence of alkaloids (Martins et al., 2005; Pistelli et al., 2001) flavonoids and isoflavonoids (Pistelli et al., 1998, 2000; Giachi et al., 2002; Tosun et al., 2009), which are chemotaxonomic markers of the genus (Harborne, 1994). As a part of our ongoing research on new bioactive compounds from endemic plants of Algeria, we have studied the aerial parts of Genista ulicina Spach. In the present paper, we describe the isolation of fourteen saponins among which six (1-6) are isolated for the first time, and six known flavonoids. All compounds were identified by extensive spectroscopic methods including 1D- $\left({ }^{1} \mathrm{H}\right.$ and $\left.{ }^{13} \mathrm{C}\right)$ and 2D-NMR (COSY, HSQC, HMBC, ROESY and TOCSY) experiments as well as HR-ESI-MS analysis and by comparison of their spectral data with the literature values for the known compounds. To our best knowledge, this is the first report of saponins in Genista genus. 


\section{Results and discussion}

\subsection{Isolation and identification of new compounds $\mathbf{1 - 6}$}

The $n$-butanol-soluble part partitioned from the methanol extract of G. ulicina was submitted to vacuum liquid chromatography (VLC) on reversed phase $\mathrm{C}_{18}$ (RP-18) to afford six subfractions. Purification by a series of column chromatographies over silica gel and reverse phase $\mathrm{C}_{18}$ and finally by HPLC afforded fourteen saponins from which six are new (1-6) along with six known flavonoids. The known compounds were identified as: $3-O-\beta$-Dgalactopyranosyloleanolic 28-O- $\beta$-D-glucopyranosyl ester (Sha et al., 2008), soyasaponin I (Kitagawa et al., 1976, Rao et al., 1985), soyasaponin III (Kitagawa et al., 1976, Kudou et al., 1993), sandosaponin A (Yoshikawa et al., 1997), dehydrosoyasaponin I (Miyao et al., 1996; Konoshima et al., 1991), kaikasaponin I (Kitagawa et al., 1988), kaikasaponin III (Kitagawa et al., 1988, Miyao et al., 1996), phaseoside IV (Miyao et al., 1996), biochanin A (Santos et al., 1995), kaempferol 3-O- $\beta$-D-apiofuranosyl-(1 $\rightarrow 2)$-[ $\alpha$-L-rhamnopyranosyl$(1 \rightarrow 6)]$ - $\beta$-D-glucopyranoside (Piccinelli et al., 2007), rutin (Bourama et al., 2004), isovitexin (Krafczyk et al., 2008), isorhamnetin-3- $O$-rutinoside (Shibano et al., 1996), 6,8-di- $C$ - $\beta$-Dglucopyranosylapigenin (Krafczyk et al., 2008). The sugar composition of all compounds in $\mathrm{BuOH}$ extract was identified as glucose, galactose, glucuronic acid and rhamnose by TLC after acid hydrolysis of the $n$-butanol-soluble fraction. Their absolute configuration was determined to be D for glucose, galactose, and glucuronic acid and L for rhamnose, after preparative TLC and measurement of the optical rotation of each sugar.

The positive HR-ESI-MS of the saponin 1 showed a pseudo-molecular ion peak $[\mathrm{M}+\mathrm{Na}]^{+}$at $m / z, 659.4144$ in accordance with a $\mathrm{C}_{36} \mathrm{H}_{60} \mathrm{O}_{9} \mathrm{Na}$ formula indicating that it contained one hexose unit. The presence of one sugar moiety in $\mathbf{1}$ was evidenced by the ${ }^{1} \mathrm{H}$ NMR spectrum which displayed one anomeric proton at $\delta_{\mathrm{H}} 4.34(\mathrm{~d}, J=7.8 \mathrm{~Hz})$ and identified after analysis of COSY and HSQC spectra as a glucose (Table 1). The $\beta$ anomeric configuration of glucose 
was defined from its ${ }^{3} J_{\mathrm{H} 1, \mathrm{H} 2}$ coupling constant as well as from rOe information (Jia et al.,1998; Zhang et al., 1999). The ${ }^{1} \mathrm{H}$ NMR spectrum of $\mathbf{1}$ showed signals of an olean-12-ene type aglycone (Mahato et al., 1994), five methyl singlets, one olefinic proton signal at $\delta_{\mathrm{H}} 5.64(\mathrm{t}, J=3.3 \mathrm{~Hz}, \mathrm{H}-12)$, one oxygen-bearing methine proton signal at $\delta_{\mathrm{H}} 3.20(\mathrm{dd}, J=$ $11.3,5.3 \mathrm{~Hz}, \mathrm{H}-3)$, three primary alcoholic functions at $\delta_{\mathrm{H}} 3.20$ and $3.57(\mathrm{~d}, J=11.1 \mathrm{~Hz}$, each, H-28a, H-28b), 3.45 and 3.49 (d, $J=11.0 \mathrm{~Hz}$, each, H-30a, H-30b), and 3.55 and 3.82 (d, $J=$ 12.3 Hz, each, H-27a, H-27b). The assignments of the proton and carbon signals and the positions of primary alcoholic functions of $\mathbf{1}$ were established by analysis of COSY, HSQC and $\mathrm{HMBC}$ spectra. The protons at $\delta_{\mathrm{H}} 3.55$ and 3.82 showed $\mathrm{HMBC}$ correlations with $\mathrm{C}-8$ at $\delta_{\mathrm{C}} 40.2, \mathrm{C}-13$ at $\delta_{\mathrm{C}} 138.4, \mathrm{C}-14$ at $\delta_{\mathrm{C}} 46.9$ and C-15 at $\delta_{\mathrm{C}} 21.1$, which revealed the location of the first alcoholic function at position 27. The ROESY spectra showed a correlation between an axial proton at $\delta_{\mathrm{H}} 2.05$, assigned to $\mathrm{H}-18(\mathrm{dd}, J=13.8,4.2 \mathrm{~Hz})$, and axial protons at $\delta_{\mathrm{H}}$ $3.45(\mathrm{H}-30 \mathrm{a})$ and $3.49(\mathrm{H}-30 \mathrm{~b})$. This indicated the position of the second hydroxyl group at C30. Furthermore, based on $\mathrm{HMBC}$ correlations between protons at $\delta_{\mathrm{H}} 3.20$ and 3.57 and $\mathrm{C}-18$ at $\delta 41.4, \mathrm{C}-16$ at $\delta 22.0$, and $\mathrm{C}-21$ at $\delta 28.8$, the third primary alcoholic function were assigned at C-28 position. The full assignments of the protons and carbons of $\mathbf{1}$ were achieved by combination of ${ }^{1} \mathrm{H},{ }^{13} \mathrm{C}$, DEPT, COSY, HSQC, HMBC and ROESY experiments. The linkage of the glucose at $\mathrm{C}_{3}$ of aglycone was established from the HMBC correlation between Glc- H-1' $\left(\delta_{\mathrm{H}} 4.34\right)$ with aglycone C-3 $\left(\delta_{\mathrm{C}} 89.4\right)$. Based on the above evidence, the structure of 1 was established as 3-O- $\beta$-D-glucopyranosyl-olean-12-ene-3 $\beta, 27,28,30$-tetraol.

A comparison of NMR data of saponin 1 with the new isolated saponins (2-6) showed the presence of a glucose moiety linked at position C-3 of their aglycone (Tables 1 and 2).

Saponin 2 was an isomer of saponin $1\left(\mathrm{C}_{36} \mathrm{H}_{60} \mathrm{O}_{9}\right)$, as deduced from the HR-ESI-MS positive ion mode which showed a $[\mathrm{M}+\mathrm{Na}]^{+}$ion peak at $\mathrm{m} / \mathrm{z} 659.4128$. The analysis of the $2 \mathrm{D}-\mathrm{NMR}$ (COSY, HSQC, HMBC and ROESY) data of compound 2 displayed the signals characteristic 
of a $\Delta^{12}$ oleanene skeleton derivative with three primary alcoholic functions and $\beta$-D-glucose as in 1. Significant differences between these two isomers observed in the ${ }^{13} \mathrm{C}$ NMR spectrum were the upfield shift of C-29 ( $\Delta 46.6 \mathrm{ppm})$, and the downfield shift of C-30 ( $\Delta 47.1 \mathrm{ppm})$ compared to the corresponding signals in $\mathbf{1}$. The chemical shifts of $\mathrm{C}-29\left(\delta_{\mathrm{C}} 73.2\right)$ was found shifted to higher field suggesting a free primary alcoholic function at C-29 in 2, instead of C30 as in 1. This was confirmed by the rOe correlation observed between an axial proton at $\delta_{\mathrm{H}} 2.12$, assigned to $\mathrm{H}-18$, and $\mathrm{H}-30$. Accordingly, the structure of 2 was elucidated as 3-O- $\beta$ D-glucopyranosyl-olean-12-ene-3ß,27,28,29-tetraol.

Saponin 3 exhibited in the HR-ESI-MS a quasi molecular ion peak at $m / z 821.4671[\mathrm{M}+\mathrm{Na}]^{+}$ corresponding to the molecular formula of $\mathrm{C}_{42} \mathrm{H}_{70} \mathrm{O}_{14}+\mathrm{Na}$, suggesting that this compound possessed a supplementary hexose unit in comparison with saponins $\mathbf{1}$ and $\mathbf{2}$. This hypothesis was confirmed by the ${ }^{1} \mathrm{H}$ NMR spectrum which displayed two anomeric protons at $\delta_{\mathrm{H}} 4.23(\mathrm{~d}$, $J=7.8 \mathrm{~Hz})$ and $4.34(\mathrm{~d}, J=7.8 \mathrm{~Hz})$, giving correlations in the HSQC spectrum with two anomeric carbons at $\delta_{\mathrm{C}} 103.5$ and 105.4 , respectively. The evaluation of spin-spin couplings and chemical shifts allowed the identification of two $\beta$-glucopyranosyl moities. The ${ }^{1} \mathrm{H}$ and ${ }^{13} \mathrm{C}$ NMR signals of the aglycone moiety was superimposable to saponin $\mathbf{2}$ except for signals of C-29 deshielded at $\delta_{\mathrm{C}} 80.8$, suggesting the same aglycone as in $\mathbf{2}$ with substitution of the primary alcohol in C-29 by the second glucopyranosyl moiety. The HMBC correlation between anomeric proton at $\delta_{\mathrm{H}} 4.23(\mathrm{Glc} \mathrm{H}-1 ")$ and $\delta_{\mathrm{C}} 80.8(\mathrm{C}-29)$ proved the location of the supplementary glucose at C-29, and this is confirmed by the ROESY cross peak $\delta_{\mathrm{H}} 4.23 / 3.17$ (Glc H-1"/ H-29). On the basis of above results, the structure of saponin 3 is 3,29-di-O- $\beta-\mathrm{D}-$ glucopyranosyl-olean-12-ene-3ß,27,28,29-tetraol.

Saponin 4 gave a $[\mathrm{M}+\mathrm{Na}]^{+}$pseudomolecular ion peak at $\mathrm{m} / \mathrm{z} 673.4671$ in positive HR-ESIMS, 14 mass units higher than that of 2. Detailed comparison of the NMR data of 4 and 2 concluded that both compounds shared a common sugar with a difference for the aglycone 
moieties. In the ${ }^{13} \mathrm{C}$ NMR of $\mathbf{4}$, the signal due to primary alcoholic function at C-27 in $\mathbf{2}\left(\delta_{\mathrm{C}}\right.$ 63.2) was replaced by a resonance at $\delta_{C}$ 178.8. This, together with the MS data, clearly indicated that compound 4 had a carboxylic function in C-27 position. The change in chemical shifts of C-14 [ $\delta_{C} 46.9$ in 2 and 55.9 in 4 ] and C-7 [ $\delta_{C} 32.7$ in 2 and 36.5 in 4 ] supported this assignment (Table 1). The structure of $\mathbf{4}$ was thus determined as $3-O-\beta-\mathrm{D}-$ glucopyranosyl-olean-12-ene-3ß,28,29-triol-27-oic acid.

Saponin 5 had the same molecular formula of $\mathrm{C}_{36} \mathrm{H}_{58} \mathrm{O}_{10}$ as $\mathbf{4}$, as indicated by HR-ESI-MS. The ${ }^{1} \mathrm{H}$ NMR and ${ }^{13} \mathrm{C}$ NMR signals of $\mathbf{5}$ assigned from extensive 2D NMR analysis showed that $\mathbf{5}$ is very similar to $\mathbf{4}$, since it possessed the same constitutive elements, an aglycone of $\Delta^{12}$ oleanene derivative, two primary alcoholic and one carboxylic functions. The compounds $\mathbf{5}$ and $\mathbf{4}$ differ only by the position of the carboxylic function in the aglycone part (Tables 1 and 2). Comparison of the ${ }^{13} \mathrm{C}$ NMR data of 5 with that of 4 indicated the change in chemical shifts of C-27 [ $\delta_{C} 178.8$ in 4 and 63.3 in 5] and C-29 [ $\delta_{C} 73.0$ in 4 and 181.5 in 5]. Furthermore the correlation in the HMBC spectrum between $\delta_{\mathrm{H}}$ at $1.24\left(\mathrm{CH}_{3}-30\right)$ and $\delta_{\mathrm{C}}$ at 181.5 revealed the location of the carboxylic function at C-29 in 5. From the above discussion, the structure of $\mathbf{5}$ was assigned as 3-O- $\beta$-D-glucopyranosyl-olean-12-ene3ß,27,28-triol-29-oic acid.

Saponin 6 was assigned a molecular formula of $\mathrm{C}_{35} \mathrm{H}_{58} \mathrm{O}_{8}$, as deduced from its positive ion in HR-ESI-MS which exhibited a quasi molecular ion peak at $m / z 629.4033[\mathrm{M}+\mathrm{Na}]^{+}, 44$ mass units lower than that of 4, implying the absence of the carboxylic function in $\mathbf{6}$. Among the 35 carbons in ${ }^{13} \mathrm{C}$ NMR spectrum, 29 were assigned to the triterpenoid aglycone and 6 of the sugar moiety. Extensive NMR spectroscopic analysis indicated that $\mathbf{6}$ and $\mathbf{4}$ are structurally different only in the substituent in C-14 position of the aglycone. The lack of a substitution in this C-14 position in $\mathbf{6}$ was supported by the presence of HMBC correlation between C-13 and proton at $\delta_{\mathrm{H}} 1.93(1 \mathrm{H}, \mathrm{m}, \mathrm{H}-14)$, and by the significant chemical shift difference for C-14 [ $\Delta$ 
7.8] between 6 and olean $\Delta^{12}$ ene type (Table 2) (Mahato et al., 1994). Accordingly, the structure of 6 was elucidated as 3-O- $\beta$-D-glucopyranosyl-14- $H$-27-nor-olean-12-ene-3 $\beta, 28,29$ triol.

\subsection{Cytotoxicity results}

On the basis of the activity reported for the triterpene saponin derivatives isolated from the Fabaceae family (Verrota et al., 2001), the cytotoxic activity of the $n$-butanol extract was tested against the HT-29 human colon cancer cell line using a MTT assay (Mosmann, 1983). No significant activity was found in these bioassays ( $\mathrm{IC}_{50}>100 \mu \mathrm{g} / \mathrm{mL}$ ).

\section{Conclusions}

Six new triterpenoid saponins (1-6), and 14 known compounds were isolated from the $n$ $\mathrm{BuOH}$ extract of the aerial parts of G. ulicina. Their structures were elucidated by extensive spectroscopic examinations. To our knowledge this is the first report of triterpene saponins in Genista genus which is known to contain alkaloids and flavonoids. The new saponins (1-6) contained glucose in position 3 of the aglycone, whereas the oleanene triterpenoid skeleton contained primary alcoholic function in C-28 and primary alcoholic or carboxylic functions in C-27, C-29 or C-30, it is also worthwhile to mention that the compound 6 had 27-noroleanene aglycone. The seven known isolated saponins exhibit a glucuronic acid but not glucose attached at C-3 and are characteristic of Fabaceae plants. Thus, the finding of oleanane-type triterpene saponin may provide a significant chemotaxanomic proof for Genista genus. The results of the present phytochemical study are in agreement with the flavonoidic patterns in the tribe Genisteae reported by Harborne (Harborne, 1994).

\section{Experimental}




\subsection{General experimental procedures}

Optical rotations were measured in $\mathrm{MeOH}$ or $\mathrm{CHCl}_{3}$ with a Perkin-Elmer 241 polarimeter. ${ }^{1} \mathrm{H}$ and ${ }^{13} \mathrm{C}$ NMR spectra were recorded on a Bruker Avance III 500 spectrometer $\left({ }^{1} \mathrm{H}\right.$ at 500 $\mathrm{MHz}$ and ${ }^{13} \mathrm{C}$ at $125 \mathrm{MHz}$ ) or on a Bruker Avance III 600 spectrometer equipped with a cryoplatform $\left({ }^{1} \mathrm{H}\right.$ at $600 \mathrm{MHz}$ and ${ }^{13} \mathrm{C}$ at $\left.150 \mathrm{MHz}\right)$. 2D-NMR experiments were performed using standard Bruker microprograms (Xwin-NMR version 2.1 software). ESIMS and HRESIMS experiments were performed using a Micromass Q-TOF micro instrument (Manchester, UK). The samples were introduced by direct infusion in a solution of $\mathrm{MeOH}$ at a rate of $5 \mu \mathrm{L} \mathrm{min}{ }^{-1}$. TLC was carried out on precoated silica gel $60 \mathrm{~F}_{254}$ (Merck), and spots were visualized by heating after spraying with $50 \% \mathrm{H}_{2} \mathrm{SO}_{4}$. Kieselgel 60 (63-200 mesh) Merck or LiChroprep RP-18 (40-63 $\mu \mathrm{m})$ Merck were used for Column chromatography (CC). HPLC was performed on a Dionex apparatus equipped with an ASI-100 autosampler, a P580 pump, a UVD 340S diode array detector, and Chromeleon ${ }^{\circledR}$ software. A prepacked RP-18 column (201SP510, $250 \times 10 \mathrm{~mm}, 5 \mu \mathrm{m}, 90 \AA$ A, Dionex, Vydac, France) was used for semi preparative HPLC of the flavonoids with a binary gradient elution (solvent $\mathrm{A}$ : $\mathrm{H}_{2} \mathrm{O}$ with $0.0025 \% \mathrm{TFA}$, solvent $\mathrm{B}: \mathrm{MeCN}$ ) at $25^{\circ} \mathrm{C}$ and a flow rate of $3.5 \mathrm{~mL} \mathrm{~min}^{-1}$; the chromatogram was monitored at 254 and $365 \mathrm{~nm}$.

\subsection{Plant material}

The aerial parts of Genista ulicina Spach were collected during the flowering stage at Taza national park (Jijel, Algeria) in May 2009 and identified by Pr. Gerard De Bélair (University of Annaba, Algeria). A voucher specimen (ZKGu05/09) was deposited in the Herbarium of Biology Department (Mentouri University, Constantine).

\subsection{Extraction and isolation of new compounds}

Powdered air-dried aerial parts of G. ulicina (1000g) were macerated in $\mathrm{MeOH}-\mathrm{H}_{2} \mathrm{O}(8: 2$, 10L). This extract was concentrated to dryness, and the residue was suspended in $\mathrm{H}_{2} \mathrm{O}(600$ 
ml), and partitioned successively with $\mathrm{CHCl}_{3}$, EtOAc and $n$-BuOH (3x 300ml each), then exhaustively concentrated to yield a $\mathrm{CHCl}_{3}$ fraction $(15 \mathrm{~g})$, EtOAc $(7 \mathrm{~g})$, and $n$ - $\mathrm{BuOH}$ fraction (20 g). $12 \mathrm{~g}$ of the $n-\mathrm{BuOH}$ fraction were submitted to VLC over RP-18, eluted with MeOH$\mathrm{H}_{2} \mathrm{O}(4: 6,6: 4,8: 2$ and $0: 10$, each $450 \mathrm{ml})$ to give six fractions $\left[\mathrm{F}_{1}: 6.64 \mathrm{~g}, \mathrm{~F}_{2}: 2.18 \mathrm{~g}, \mathrm{~F}_{3}: 0.45 \mathrm{~g}\right.$, $\left.\mathrm{F}_{4}: 0.49 \mathrm{~g}, \mathrm{~F}_{5}: 1.1 \mathrm{~g}, \mathrm{~F}_{6}: 0.21 \mathrm{~g}\right]$

Fraction $\mathrm{F}_{5}(1.1 \mathrm{~g})$ was subjected to $\mathrm{RP}-18 \mathrm{CC}$ using a gradient of $\mathrm{MeOH}-\mathrm{H}_{2} \mathrm{O}$ (4:6-8:2). Fractions [220-264] (70 mg), eluted with $\mathrm{MeOH}-\mathrm{H}_{2} \mathrm{O}(55: 45)$ were purified by silica gel CC, eluted with $\mathrm{CHCl}_{3}-\mathrm{MeOH}-\mathrm{H}_{2} \mathrm{O}$ [95:5:0-30:70:5], to give (4.5 mg) of 5. Fraction [29-47] (36 mg), eluted with $\mathrm{CHCl}_{3}-\mathrm{MeOH}(85: 15)$, were purified by semi prep HPLC using an isocratic gradient of 30\% B during $20 \mathrm{~min}$ to yield $\mathbf{3}(2.6 \mathrm{mg})$ and $\mathbf{5}(1.5 \mathrm{mg})$. Fractions [265-284] (138 mg), eluted $\mathrm{MeOH}-\mathrm{H}_{2} \mathrm{O}(6: 4)$, were purified by silica gel $\mathrm{CC}$, using a gradient of $\mathrm{CHCl}_{3}-$ $\mathrm{MeOH}$ [95:5-85:15]. Fractions [39-47] (20.6 mg) and [86-112] (18.8 mg) eluted, respectively with $\mathrm{CHCl}_{3}-\mathrm{MeOH}$ [93:7] and [9:1], were purified by semi preparative HPLC using isocratic elution with $30 \% \mathrm{~B}$ for $30 \mathrm{~min}$ to give $\mathbf{1}(4.3 \mathrm{mg}), \mathbf{2}(4.6 \mathrm{mg}), \mathbf{5}(5 \mathrm{mg})$ and $4(2.7 \mathrm{mg})$. Fractions [351-357] (40.3 mg), eluted with $\mathrm{MeOH}-\mathrm{H}_{2} \mathrm{O}$ (7:3), contained $2.1 \mathrm{mg}$ of 6, which were purified by semi prep HPLC using an isocratic gradient at $40 \%$ B for $15 \mathrm{~min}$.

\subsection{Saponin 1}

White amorphous powder; $[\alpha]_{\mathrm{D}}+18.9(c 0.28, \mathrm{MeOH}) ;{ }^{1} \mathrm{H}$ and ${ }^{13} \mathrm{C}$ NMR $\left(\mathrm{CD}_{3} \mathrm{OD}\right)$, see Table 1. HRESIMS (positive-ion mode) $m / z 659.4144[\mathrm{M}+\mathrm{Na}]^{+}\left(\right.$calcd for $\left.\mathrm{C}_{36} \mathrm{H}_{60} \mathrm{O} 9 \mathrm{Na}, 659.4135\right)$.

\subsection{Saponin 2}

White amorphous powder; $[\alpha]_{\mathrm{D}}+18.6(c 0.57, \mathrm{MeOH}) ;{ }^{1} \mathrm{H}$ and ${ }^{13} \mathrm{C} \mathrm{NMR}\left(\mathrm{CD}_{3} \mathrm{OD}\right)$, see Table 1. HRESIMS (positive-ion mode) $m / z 659.4128[\mathrm{M}+\mathrm{Na}]^{+}$(calcd for $\mathrm{C}_{36} \mathrm{H}_{60} \mathrm{O}_{9} \mathrm{Na}, 659.4135$ ).

\subsection{Saponin 3}

White amorphous powder; $[\alpha]_{\mathrm{D}}+14.8(c 0.25, \mathrm{MeOH}) ;{ }^{1} \mathrm{H}$ and ${ }^{13} \mathrm{C}$ NMR $\left(\mathrm{CD}_{3} \mathrm{OD}\right)$, see Table 1. HRESIMS (positive-ion mode) $m / z 821.4671[\mathrm{M}+\mathrm{Na}]^{+}$(calcd for $\mathrm{C}_{42} \mathrm{H}_{70} \mathrm{O}_{14} \mathrm{Na}, 821.4663$ ). 


\subsection{Saponin 4}

White amorphous powder; $[\alpha]_{\mathrm{D}}+24(c 0.75, \mathrm{MeOH}) ;{ }^{1} \mathrm{H}$ and ${ }^{13} \mathrm{C}$ NMR $\left(\mathrm{CD}_{3} \mathrm{OD}\right)$, see Table 1 . ESIMS (positive-ion mode) $\mathrm{m} / z 673.6[\mathrm{M}+\mathrm{Na}]^{+}$; HRESIMS (positive-ion mode) $\mathrm{m} / \mathrm{z}$ $673.3921[\mathrm{M}+\mathrm{Na}]^{+}$(calcd for $\left.\mathrm{C}_{36} \mathrm{H}_{58} \mathrm{O}_{10} \mathrm{Na}, 673.3928\right)$.

\subsection{Saponin 5}

White amorphous powder; $[\alpha]_{\mathrm{D}}+6.3(c 0.35, \mathrm{MeOH}) ;{ }^{1} \mathrm{H}$ and ${ }^{13} \mathrm{C}$ NMR $\left(\mathrm{CD}_{3} \mathrm{OD}\right)$, see Table

2. HRESIMS (positive-ion mode) $\mathrm{m} / z$ 673.3933 $[\mathrm{M}+\mathrm{Na}]+{ }^{+}$(calcd for $\mathrm{C}_{36} \mathrm{H}_{58} \mathrm{O}_{10} \mathrm{Na}$, 673.3928).

\subsection{Saponin 6}

White amorphous powder; $[\alpha]_{\mathrm{D}}+15.8(c 0.19, \mathrm{MeOH}) ;{ }^{1} \mathrm{H}$ and ${ }^{13} \mathrm{C}$ NMR $\left(\mathrm{CD}_{3} \mathrm{OD}\right)$, see Table 2. HRESIMS (positive-ion mode) $\mathrm{m} / z, 629.4033[\mathrm{M}+\mathrm{Na}]^{+}$(calcd for $\mathrm{C}_{35} \mathrm{H}_{58} \mathrm{O}_{8} \mathrm{Na}, 629.4029$ ). 4.10. Acid hydrolysis

A part of the $n-\mathrm{BuOH}$ fraction $(1 \mathrm{~g})$ was refluxed in $2 \mathrm{~N} \mathrm{HCl}(30 \mathrm{~mL})$ for $4 \mathrm{~h}$. The reaction mixture was neutralized with $0.5 \mathrm{~N} \mathrm{KOH}$ and freeze-dried. Four sugars were identified and compared with authentic samples by TLC using MeCOEt-iso-PrOH-Me ${ }_{2} \mathrm{CO}-\mathrm{H}_{2} \mathrm{O}$ (20:10:7:6) as D-glucuronic acid, D-glucose, D-galactose and L- rhamnose. After the purification of these sugars by preparative TLC in the same solvent, the optical rotation of each purified sugar was measured.

\subsection{MTT cytotoxicity assay}

The bioassay was performed according to the [3-(4,5-dimethylthiazol-2-yl)-2,5diphenyltetrazolium bromide] MTT (Sigma, St. Quentin Fallavier, France) assay method as described by Mosmann, 1983 with human colorectal cancer cell line (HT-29).

\section{Acknowledgments}


The authors are grateful to the Ministry of Higher Education and Scientific Research (Algeria) for financial support. Financial support by CNRS, Conseil Regional Champagne Ardenne, Conseil General de la Marne, Ministry of Higher Education and Research (MESR) and EU-programme FEDER to the PIANET CPER project is gratefully acknowledged.

\section{References}

Bourama, N., Byung-Hun, U., Lobstein, A., Weniger,B., Koné, M., Anton, R., 2004. Flavonoides de Tephrosia deflexa et Tephrosia albifoliolis. C. R.C. 7, 993-996.

Garritano, S., Pinto, B., Giachi, I., Pistelli, L., Reali, D., 2005. Assessment of estrogenic activity of flavonoids from Mediterranean plants using an in vitro short-term test. Phytomedicine. 12, 143-147.

Giachi, I., Manunta, A., Morelli, I., Pistelli, L., 2002. Flavonoids and isoflavonoids from Genista morisii. Biochem. Syst. Ecol. 30, 801-803.

Harborne, J.B., 1994. In: Harborne, J.B. (Ed.), Phytochemical Dictionary of Leguminosae Chapman \& Hall, London, pp. 313-330.

Ilarionov, I., Rainova, L., Nakov, N., 1979. Antiinflammatory and antiulcer effect of some flavonoids isolated from the genus Genista. Farmatsiya. 29, 39- 46.

Jia, Z.H., Koike, K., Nikaido, T., 1998. Major triterpenoid saponins from Saponaria officinalis. J. Nat. Prod. 61, 1368-1373.

Kitagawa, I., Yoshikawa, M., Yosioka, I., 1976. Saponin and sapogenol XLVI. Structures of three soybean saponins: soyasaponin I, soyasaponin II and soyasaponin III. Chem. Pharm. Bull. 24, 121-129.

Kitagawa, I., Taniyana, T., Hong, W.W., Hori, K., Yoshikawa, M., 1988. Saponin and sapogenol XLV. Structures of Kaikasaponins I, II and III from Sophorae Flos, the Buds of Sophora japonica L. Chem. Pharm. Bull. 108, 538-546. 
Konoshima, T., Kozuka, M., Haruna, M., Ito, K., 1991. Constituents of Leguminous Plants, XIII. New triterpenoid saponins from Wistaria brachybotrys. J. Nat. Prod. 54, 830-836.

Korpachov, V.V., Litvinenko, O., Paster, I.P., 1995. Effect of Genista tinctoria extracts on the function of thyroid gland of intact rats and rats with experimental hypothyroidism. Farm. Zh. (Kiev). 5, 82-86.

Krafczyk, N., Kötke, M., Lehnert, N., Glomb, M., 2008. Phenolic composition of rhubarb. Eur. Food. Res. Technol. 228, 187-196.

Kudou, S., Masahide, T., Tsukamoto, C., Sakabe, T., Tamura, N., Okubo, K., 1993. Isolation and structural elucidation of DDMP conjugated soyasaponins as genuine saponins from soybean seeds. Biosci. Biotechnol. Biochem. 57, 546-550.

Luczkiewicz, M., Glod, D., 2003. Callus cultures of Genista plants in vitro material producing high amounts of isoflavones of phytoestrogenic activity. Plant Sci. 165, 1101-1108.

Mahato, S.B., Kundu, A.P. 1994. ${ }^{13}$ C NMR Spectra of pentacyclic triterpenoids-a compilation and some salient features. Phytochemistry. 37, 1517-1575.

Martins, A., Wink, M., Tei, A., Brum-Bousquet, M., Tillequin, F., Rauter, A.P., 2005. Phytochemical study of quinolizidine alkaloids from Genista tenera by gas-liquid chromatography/mass spectrometry. Phytochem. Anal. 16, 264.

Miyao, H.; Sakai, Y., Takeshita, T., Kinjo, J., Nohara, T., 1996. Triterpene saponins from Abrus cantoniensis (Leguminosae). I. Isolation and characterization of four new saponins and a new sapogenol. Chem. Pharm. Bull. 44, 1222-1227.

Mosmann, T., 1983. Rapid colorimetric assay for cellular growth and survival: Application to proliferation and cytotoxicity assays. J. Immunol. Meth, 65, 55-63.

Noccioli, C., Meini, L., Cecilia Loi, M., Potenza, D., Pistelli, L., 2011. A new alpinumisoflavone derivative from Genista pichisermolliana. Phytochem Lett. 4, 342-344. 
Piccinelli, A., Veneziano, A., Passi, S., Simone, F., Rastrelli, L., 2007. Flavonol glycosides from whole cottonseed by-product. Food Chem. 100, 344-349.

Pistelli, L., Bertoli, A., Giachi, I., Manunta, A., 1998. Flavonoids from Genista ephedroides. J. Nat. Prod. 61, 1404-1406.

Pistelli, L., Giachi, I., Potenza, D., Morelli, I., 2000. A New Isoflavone from Genista corsica. J. Nat. Prod. 63, 504-506.

Pistelli, L., Bertoli, A., Giachi, I., Morelli, I., Rubiolo, P., Bicchi, C., 2001. Quinolizidine alkaloids from Genista ephedroides. Biochem. Syst. Ecol. 29, 137-141.

Quezel, P., Santa, S., 1963. Nouvelle flore de l'Algérie et des régions désertiques Méridionales, CNRS, Paris, Vol. 2, pp 1170.

Rainova, L., Nakov, N., Bogdanova, S., Minkov, E., Staneva-Stoicheva, D., 1988. Ulceroprotective activity of the flavonoids of Genista rumelica Vel. Phytother. Res. 2, 137139.

Rao, G.V., Rao, P.S., Tomimori, T., Kizu, H., 1985. Soyasaponin I from Rothia trifoliata. J. Nat. Prod. 48, 135-138.

Rauter, A.P., Martins A., Borges, C., Ferreira, J., Justino, J., Bronze, M. R., Coelho, A.V., Choi, Y.H., Verpoorte, R., 2005. Liquid chromatography-diode array detection-electrospray ionization mass spectrometry nuclear magnetic resonance analyses of the anti-hyperglycemic flavonoid extract of Genista tenera. Structure elucidation of a flavonoid-C-glycoside. J. Chromatogr. A. 1089, 59-64.

Rauter, A. P., Martins, Al., Lopes, R., Ferreira, J., Serralheiro,L. M., Araujo, M., Borges, C., Justino, J., Silva, F., Goulart, M., Thomas-Oates., Rodrigues, J. A., Edwards, E., Noronha, J., Helder Mota-Filipe, R. P., 2009. Bioactivity studies and chemical profile of the antidiabetic plant Genista tenera. J. Ethnopharmacol. 122, 384-393. 
Rigano, D., Cardile, V., Formisano, C., Maldinic, M. T, Piacente, S., Bevilacqua, J., Russo, A., Senatore, F., 2009. Genista sessilifolia DC, and Genista tinctoria L. inhibit UV light and nitric oxide-induced DNA damage and human melanoma cell growth. Chem. Biol. Intera. 18, 211-219.

Rigano, D., Russo, A., Formisano, C., Cardile, V., Senatore, F., 2010. Antiproliferative and cytotoxic effects on malignant melanoma cells of essential oils from the aerial parts of Genista sessilifolia and G. tinctoria. Nat. Prod.Commun. 5, 1127-1132.

Santos, S.A., Carvalho, M.G., 1995. Unambiguous ${ }^{1} \mathrm{H}$ and ${ }^{13} \mathrm{C}$ NMR-assignments of isoflavones from Virola caducifolia. J. Braz.Chem. Soc. 4, 349-352.

Sha, Y., Yan, M.-C., Liu, J., Liu, Y., Cheng, M.-S., 2008. Facile Synthesis of Oleanolic Acid Monoglycosides and Diglycosides. Molecules. 13, 1472-1486.

Shibano, M., Matsumoto ,Y., Kusano, G., Shibata, T., 1996. Researches of Glycyrrhiza species grown at medicinal plant gardens in Japan and basic studies for selection of pharmaceutically fine races. 1. Comparative studies by HPLC patterns and constituents of aerial parts. Nat. Med. 50, 273-283.

Ting, G., Hui, Yao., Jingyuan, S., Chang, L., Yingjie, Z., Xinye, M., Xiaohui, P., Hongxi, X., Shilin, C., 2010. Identification of medicinal plants in the family Fabaceae using a potential DNA barcode ITS2. J. Ethnopharmacol. 130, 116-121.

Tosun, F., Akyuz Kizilay, C., and Tosun, A. U., 2009. Flavonoids and isoflavonoids from Genista sessilifolia growing in Turkey. Chem. Nat. Comp. 45, 83-84.

Verotta, L., El-Sebakhy, N. A., 2001. In Studies in Natural Products Chemistry; Atta-urRahman, Ed.; Elsevier: Amsterdam. 25, 179-234.

Yoshikawa, M., Shimada, H., Komatsu, H., Sakurama, T., Nishida, N., Yamahara, J. Shimoda, H., Matsuda, H., Tani, T., 1997. Medicinal foodstuffs. VI. Histamine release 
inhibitors from kidney bean, the seeds of Phaseolus vulgaris L: chemical structures of sandosaponins A and B. Chem. Pham. Bull. 45, 877-882.

Zhang, Z.Z., Koike, K., Jia, Z.H., Nikaido, T., Guo, D.A., Zheng, J.H., 1999. Gleditsiosides N-Q, New triterpenoid saponins from Gleditsia sinensis. J. Nat. Prod. 62, 877-881. 


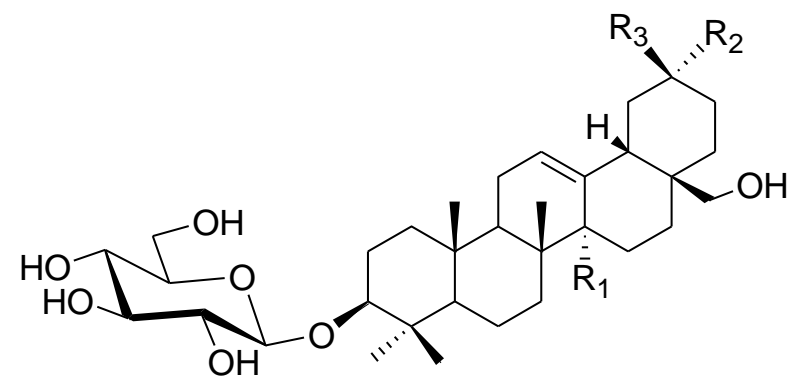

\begin{tabular}{|c|c|c|c|}
\hline & $\mathbf{R}_{1}$ & $\mathbf{R}_{2}$ & $\mathbf{R}_{3}$ \\
\hline 1 & $\mathrm{CH}_{2} \mathrm{OH}$ & $\mathrm{CH}_{3}$ & $\mathrm{CH}_{2} \mathrm{OH}$ \\
\hline 2 & $\mathrm{CH}_{2} \mathrm{OH}$ & $\mathrm{CH}_{2} \mathrm{OH}$ & $\mathrm{CH}_{3}$ \\
\hline 3 & $\mathrm{CH}_{2} \mathrm{OH}$ & $\mathrm{CH}_{2} \mathrm{O}-\mathrm{Glc}$ & $\mathrm{CH}_{3}$ \\
\hline 4 & $\mathrm{COOH}$ & $\mathrm{CH}_{2} \mathrm{OH}$ & $\mathrm{CH}_{3}$ \\
\hline 5 & $\mathrm{CH}_{2} \mathrm{OH}$ & $\mathrm{COOH}$ & $\mathrm{CH}_{3}$ \\
\hline 6 & $\mathrm{H}$ & $\mathrm{CH}_{2} \mathrm{OH}$ & $\mathrm{CH}_{3}$ \\
\hline
\end{tabular}

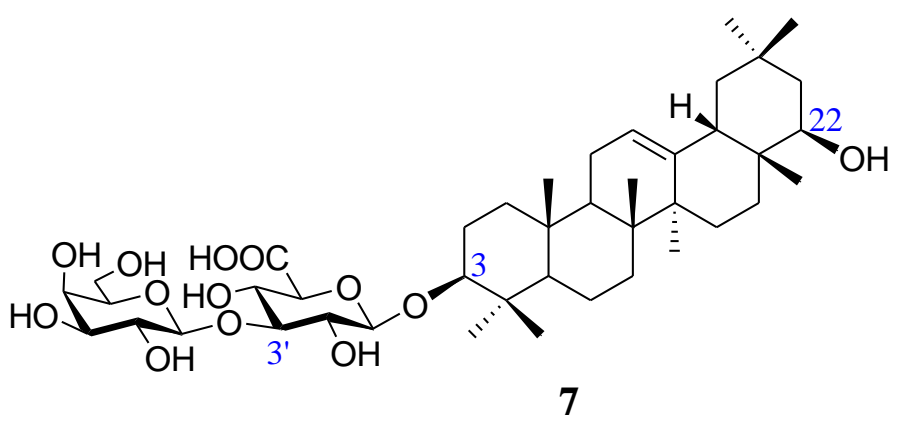

Fig. 1. Structures of compounds 1-7. 
Table1 NMR spectroscopic data (CD $\left.\mathrm{CD}_{3} \mathrm{OD}\right)$ of compounds $\mathbf{1 , 3 - 4}$ at $500 \mathrm{MHz}$ and 2 at 600 MHz.

\begin{tabular}{|c|c|c|c|c|c|c|c|c|}
\hline & \multicolumn{2}{|r|}{1} & \multicolumn{2}{|r|}{2} & \multicolumn{2}{|r|}{3} & \multicolumn{2}{|r|}{4} \\
\hline & $\delta_{\mathrm{C}}$ & $\delta_{\mathrm{H}}(J$ in $\mathrm{Hz})$ & $\delta_{\mathrm{C}}$ & $\delta_{\mathrm{H}}(J$ in $\mathrm{Hz})$ & $\delta_{\mathrm{C}}$ & $\delta_{\mathrm{H}}(J$ in $\mathrm{Hz})$ & $\delta_{\mathrm{C}}$ & $\delta_{\mathrm{H}}(J$ in $\mathrm{Hz})$ \\
\hline 1 & 38.4 & $\begin{array}{l}\text { 1.04, td }(11.9,3.3) \\
1.61, \mathrm{dm}(11.9)\end{array}$ & 38.3 & $\begin{array}{l}1.03, \mathrm{~m} \\
1.51, \mathrm{~m}\end{array}$ & 38.4 & $\begin{array}{l}1.052, \mathrm{td}(14.2,3.8) \\
1.63, \mathrm{dm}(14.2)\end{array}$ & 38.5 & $\begin{array}{l}1.03, \mathrm{~m} \\
1.68, \mathrm{~d}(13.4)\end{array}$ \\
\hline 2 & 25.6 & $\begin{array}{l}1.71, \mathrm{~m} \\
1.94, \mathrm{~m} \\
\end{array}$ & 25.6 & $\begin{array}{l}1.70, \mathrm{~m} \\
1.95, \mathrm{~m}\end{array}$ & 25.6 & $\begin{array}{l}1.71, \mathrm{td}(13.6,3.4) \\
1.95, \mathrm{~m}\end{array}$ & 25.7 & $\begin{array}{l}1.70, \mathrm{tm}(13.4) \\
1.95, \mathrm{~m}\end{array}$ \\
\hline 3 & 89.4 & $3.20, \mathrm{dd}(11.3,5.3)$ & 89.4 & $3.20, \mathrm{dd}(11.9,4.1)$ & 89.4 & $3.20, \mathrm{~m}$ & 89.3 & $3.16, \mathrm{~m}$ \\
\hline 4 & 38.8 & - & 38.8 & - & 38.8 & - & 38.7 & - \\
\hline 5 & 55.4 & $0.91, \mathrm{dm}(12.8)$ & 55.4 & $0.92, \mathrm{~m}$ & 55.4 & $0.91, \mathrm{dm}(10.4)$ & 55.6 & $0.79, \mathrm{dm}(11.6)$ \\
\hline 6 & 17.9 & $\begin{array}{l}1.45, \mathrm{td}(11.8,2.6) \\
1.61, \mathrm{dm}(11.9)\end{array}$ & 17.9 & $\begin{array}{l}1.47, \mathrm{td}(13.2,3.7) \\
1.61, \mathrm{~m}\end{array}$ & 17.9 & $\begin{array}{l}1.46, \mathrm{dm}(14.2) \\
1.63, \mathrm{~m}\end{array}$ & 17.9 & $\begin{array}{l}1.40, \mathrm{~m} \\
1.56, \mathrm{~m}\end{array}$ \\
\hline 7 & 32.8 & $\begin{array}{l}1.39, \mathrm{dm}(11.3) \\
1.71, \mathrm{~m}\end{array}$ & 32.7 & $\begin{array}{l}1.38, \mathrm{dt}(13.2,2.8) \\
1.70, \mathrm{~m}\end{array}$ & 32.7 & $\begin{array}{l}1.38, \mathrm{~d}(13.1) \\
1.68, \mathrm{td}(12.8,4.9)\end{array}$ & 36.5 & $\begin{array}{l}1.32, \mathrm{~m} \\
1.68, \mathrm{dm}(13.4)\end{array}$ \\
\hline 8 & 40.2 & - & 40.2 & - & 40.2 & - & 39.4 & - \\
\hline 9 & 48.4 & $1.98, \mathrm{dd}(9.7,7.6)$ & 48.1 & $1.98, \mathrm{t}(8.2)$ & 48.1 & $2.03, \mathrm{t}(8.6)$ & 46.9 & $2.24, \mathrm{dd}(10.7,6.0)$ \\
\hline 10 & 36.6 & - & 36.5 & - & 36.5 & - & 36.4 & - \\
\hline 11 & 23.5 & $1.91, \mathrm{~m}$ & 23.6 & $1.92, \mathrm{~m}$ & 23.6 & $1.92, \mathrm{~m}$ & 21.5 & $1.94, \mathrm{~m}$ \\
\hline 12 & 127.9 & $5.64, \mathrm{t}(3.3)$ & 127.7 & $5.61, \mathrm{t}(3.4)$ & 127.8 & $5.63, \mathrm{t}(3.4)$ & 125.8 & $5.60, \mathrm{t}(3.0)$ \\
\hline 13 & 138.4 & - & 138.3 & - & 138.3 & - & 137.1 & - \\
\hline 14 & 46.9 & - & 46.9 & - & 46.7 & - & 55.9 & - \\
\hline 15 & 21.1 & $\begin{array}{l}1.10, \mathrm{~m} \\
1.68, \mathrm{~m}\end{array}$ & 21.2 & $\begin{array}{l}1.04, \mathrm{~m} \\
1.71, \mathrm{td}(13.7,4.9)\end{array}$ & 21.4 & $\begin{array}{l}1.00, \mathrm{~m} \\
1.72, \mathrm{td}(13.6,3.4)\end{array}$ & 21.4 & $\begin{array}{l}1.72, \mathrm{t}(12.8) \\
2.01, \mathrm{dm}(12.4)\end{array}$ \\
\hline 16 & 22.0 & $\begin{array}{l}1.23, \mathrm{dd}(13.7,3.8) \\
1.83, \operatorname{td}(14.1,4.7)\end{array}$ & 21.6 & $\begin{array}{l}1.20, \mathrm{dm}(13.7) \\
1.85, \mathrm{td}(13.7,4.7)\end{array}$ & 21.5 & $\begin{array}{l}1.19, \mathrm{dm}(12.8) \\
1.88, \operatorname{td}(13.5,4.7)\end{array}$ & 22.6 & $\begin{array}{l}1.19, \mathrm{dm}(15.0) \\
1.97, \mathrm{~m}\end{array}$ \\
\hline 17 & 36.5 & - & 37.0 & - & 37.1 & - & 37.5 & - \\
\hline 18 & 41.4 & $2.05, \mathrm{dd}(13.8,4.2)$ & 41.2 & $2.12, \mathrm{dd}(13.6,4.0)$ & 41.2 & $2.12, \mathrm{dd}(13.5,4.8)$ & 43.6 & $2.13, \mathrm{dd}(13.5,4.0)$ \\
\hline 19 & 40.6 & $\begin{array}{l}1.36, \mathrm{dm}(13.7) \\
1.53, \mathrm{t}(13.7) \\
\end{array}$ & 39.7 & $\begin{array}{l}1.08, \mathrm{~m} \\
1.67, \mathrm{t}(13.5) \\
\end{array}$ & 39.9 & $\begin{array}{l}1.26, \mathrm{dd}(13.5,3.8) \\
1.75, \mathrm{t}(13.5)\end{array}$ & 38.2 & $\begin{array}{l}1.00, \mathrm{~m} \\
1.50, \mathrm{t}(13.5) \\
\end{array}$ \\
\hline 20 & 35.0 & - & 35.7 & - & 35.1 & - & 35.7 & - \\
\hline 21 & 28.8 & $\begin{array}{l}1.24, \operatorname{td}(13.7,3.8) \\
1.44, \mathrm{dm}(13.7)\end{array}$ & 28.0 & $\begin{array}{l}\text { 1.13, dm (13.7) } \\
1.41, \mathrm{~m}\end{array}$ & 28.3 & $\begin{array}{l}1.19, \mathrm{dm}(12.8) \\
1.51, \mathrm{dd}(13.2,3.2)\end{array}$ & 28.1 & $\begin{array}{l}1.16, \mathrm{dm}(13.2) \\
1.35, \mathrm{tm}(13.2)\end{array}$ \\
\hline 22 & 30.1 & $\begin{array}{l}1.33, \mathrm{dm}(13.5) \\
1.56, \mathrm{td}(13.5,4.3)\end{array}$ & 29.9 & $\begin{array}{l}1.41, \mathrm{dm}(14.3) \\
1.60, \mathrm{~m}\end{array}$ & 29.8 & $\begin{array}{l}1.41, \mathrm{dm}(13.3) \\
1.60, \operatorname{td}(13.3,3.8)\end{array}$ & 29.7 & $\begin{array}{l}1.38, \mathrm{~m} \\
1.55, \mathrm{td}(15.3,5.0)\end{array}$ \\
\hline 23 & 27.1 & $1.09, \mathrm{~s}$ & 27.0 & $1.09, \mathrm{~s}$ & 27.1 & $1.09, \mathrm{~s}$ & 27.1 & $1.05, \mathrm{~s}$ \\
\hline 24 & 15.6 & $0.88, \mathrm{~s}$ & 15.6 & $0.88, \mathrm{~s}$ & 15.6 & $0.88, \mathrm{~s}$ & 15.6 & $0.87, \mathrm{~s}$ \\
\hline 25 & 15.2 & $0.98, \mathrm{~s}$ & 15.2 & $0.99, \mathrm{~s}$ & 15.2 & $0.99, \mathrm{~s}$ & 15.5 & $1.08, \mathrm{~s}$ \\
\hline 26 & 17.3 & $0.98, \mathrm{~s}$ & 17.3 & $0.99, \mathrm{~s}$ & 17.3 & $1.00, \mathrm{~s}$ & 17.3 & $1.05, \mathrm{~s}$ \\
\hline 27 & 63.2 & $\begin{array}{l}3.55, \mathrm{~d}(12.3) \\
3.82, \mathrm{~d}(12.3) \\
\end{array}$ & 63.2 & $\begin{array}{l}3.53, \mathrm{~d}(12.2) \\
3.83, \mathrm{~d}(12.6) \\
\end{array}$ & 63.2 & $\begin{array}{l}3.55, \mathrm{~d}(12.1) \\
3.82, \mathrm{~d}(12.2) \\
\end{array}$ & 178.8 & - \\
\hline 28 & 67.9 & $\begin{array}{l}3.20, \mathrm{~d}(11.1) \\
3.57, \mathrm{~d}(11.1) \\
\end{array}$ & 68.2 & $\begin{array}{l}3.21, \mathrm{~d}(11.1) \\
3.60, \mathrm{~d}(11.1) \\
\end{array}$ & 68.2 & $\begin{array}{l}3.20, \mathrm{~d}(9.4) \\
3.59, \mathrm{~d}(9.4)\end{array}$ & 68.4 & $\begin{array}{l}3.20, \mathrm{~d}(11.0) \\
3.54, \mathrm{~d}(11.0) \\
\end{array}$ \\
\hline 29 & 26.6 & $0.90, \mathrm{~s}$ & 73.2 & 3.20 , brs & 80.8 & $\begin{array}{l}3.17, \mathrm{~d}(9.1) \\
3.61, \mathrm{~d}(9.1)\end{array}$ & 73.0 & 3.15 , brs \\
\hline 30 & 65.3 & $\begin{array}{l}3.45, \mathrm{~d}(11.0) \\
3.49, \mathrm{~d}(11.0)\end{array}$ & 18.2 & $0.92, \mathrm{~s}$ & 18.5 & $1.00, \mathrm{~s}$ & 17.9 & $0.90, \mathrm{~s}$ \\
\hline \multicolumn{9}{|c|}{ Glc (at C-3) } \\
\hline $1^{\prime}$ & 105,3 & $4.34, \mathrm{~d}(7.8)$ & 105.4 & $4.34, \mathrm{~d}(7.8)$ & 105.4 & $4.34, \mathrm{~d}(7.8)$ & 105.3 & $4.32, \mathrm{~d}(7.8)$ \\
\hline $2^{\prime}$ & 74.3 & $3.21, \mathrm{dd}(8.6,7.8)$ & 74.3 & $3.21, \mathrm{dd}(8.9,7.8)$ & 74.3 & $3.20, \mathrm{t}(7.9)$ & 74.3 & $3.20, \mathrm{dd}(8.7,7.8)$ \\
\hline $3^{\prime}$ & 76.9 & $3.36, \mathrm{t}(8.6)$ & 76.9 & $3.36, \mathrm{t}(8.9)$ & 76.9 & $3.36, \mathrm{t}(8.8)$ & 76.9 & $3.35, \mathrm{t}(8.8)$ \\
\hline $4^{\prime}$ & 70.3 & $3.31, \mathrm{t}(8.5)$ & 70.3 & $3.31, \mathrm{t}(8.6)$ & 70.2 & $3.32, \mathrm{t}(8.7)$ & 70.3 & $3.30, \mathrm{t}(8.5)$ \\
\hline $5^{\prime}$ & 76.3 & 3.26 , ddd $(9.4,5.3,2.3)$ & 76.3 & 3.25, ddd $(9.5,5.3,2.3)$ & 76.3 & $3.25, \mathrm{~m}$ & 76.3 & 3.26 , ddd $(8.5,5.3,2.2)$ \\
\hline $6^{\prime}$ & 61.4 & $\begin{array}{l}3.68, \mathrm{dd}(11.9,2.3) \\
3.85, \mathrm{dd}(11.9,5.3)\end{array}$ & 61.4 & $\begin{array}{l}3.68, \mathrm{dd}(11.9,5.5) \\
3.85 \mathrm{dd}(11.9,2.3)\end{array}$ & 61.3 & $\begin{array}{l}3.69, \text { dd }(11.0,5.5) \\
3.85, \text { dd }(10.6,2.1)\end{array}$ & 61.4 & $\begin{array}{l}3.68, \text { dd }(11.9,5.3) \\
3.86, \text { dd }(11.9,2.2)\end{array}$ \\
\hline \multicolumn{9}{|c|}{ Glc (at C-29) } \\
\hline $1^{\prime \prime}$ & & & & & 103.5 & $4.23, \mathrm{~d}(7.8)$ & & \\
\hline $2^{\prime \prime}$ & & & & & 73.9 & $3.20, \mathrm{t}(7.9)$ & & \\
\hline $3^{\prime \prime}$ & & & & & 76.5 & $3.36, \mathrm{t}(8.8)$ & & \\
\hline $4^{\prime \prime}$ & & & & & 70.3 & $3.31, \mathrm{t}(8.7)$ & & \\
\hline $5 "$ & & & & & 76.5 & $3.25, \mathrm{~m}$ & & \\
\hline $6^{\prime \prime}$ & & & & & 61.4 & $\begin{array}{l}3.68, \mathrm{dd},(10.5,5.6) \\
3.87, \mathrm{dd},(10.5,2.1)\end{array}$ & & \\
\hline
\end{tabular}


Table2 NMR spectroscopic data $\left(\mathrm{CD}_{3} \mathrm{OD}\right)$ of compound 5 at $500 \mathrm{MHz}$ and $\mathbf{6}-\mathbf{7}$ at 600

$\mathrm{MHz}$

\begin{tabular}{|c|c|c|c|c|c|c|}
\hline & \multicolumn{2}{|l|}{5} & \multicolumn{2}{|l|}{6} & \multicolumn{2}{|l|}{7} \\
\hline & $\delta_{\mathrm{C}}$ & $\delta_{\mathrm{H}}(\mathrm{J}$ in $\mathrm{Hz})$ & $\delta_{\mathrm{C}}$ & $\delta_{\mathrm{H}}(J$ in $\mathrm{Hz})$ & $\delta_{\mathrm{C}}$ & $\delta_{\mathrm{H}}(J$ in $\mathrm{Hz})$ \\
\hline 1 & 38.4 & $\begin{array}{l}1.04, \mathrm{tm}(15.4) \\
1.61, \mathrm{~m}\end{array}$ & 38.4 & $\begin{array}{l}0.99, \mathrm{tm}(14.2) \\
1.71, \mathrm{~m}\end{array}$ & 38.3 & $\begin{array}{l}1.01, \mathrm{~m} \\
1.66, \mathrm{dt}(13.0,3.0)\end{array}$ \\
\hline 2 & 25.6 & $\begin{array}{l}1.71, \mathrm{~m} \\
1.94, \mathrm{~m}\end{array}$ & 25.7 & $\begin{array}{l}1.74, \mathrm{~m} \\
1.96, \mathrm{~m}\end{array}$ & 25.7 & $\begin{array}{l}1.75, \mathrm{tm}(13.9) \\
1.91, \mathrm{~m}\end{array}$ \\
\hline 3 & 89.4 & $3.21, \mathrm{dd}(11.7,4.2)$ & 89.4 & $3.19, \mathrm{dd}(11.8,4.6)$ & 89.9 & $3.20, \mathrm{dd}(11.7,4.4)$ \\
\hline 4 & 38.8 & - & 38.8 & - & 38.9 & - \\
\hline 5 & 55.4 & $0.92, \mathrm{dm}(13.4)$ & 55.7 & $0.86, \mathrm{~m}$ & 55.6 & $0.81, \mathrm{dm}(11.8)$ \\
\hline 6 & 17.9 & $\begin{array}{l}1.45, \mathrm{~d}(12.1) \\
1.61, \mathrm{~m}\end{array}$ & 18.1 & $\begin{array}{l}1.43, \mathrm{~m} \\
1.59, \mathrm{dm}(13.6)\end{array}$ & 17.9 & $\begin{array}{l}1.46, \mathrm{t}(12.5) \\
1.60, \mathrm{~m}\end{array}$ \\
\hline 7 & 32.7 & $\begin{array}{l}1.38, \mathrm{dm}(13.1) \\
1.72, \mathrm{~m}\end{array}$ & 41.5 & $\begin{array}{l}1.16, \mathrm{td}(13.8,2.7) \\
1.96, \mathrm{~m}\end{array}$ & 32.8 & $\begin{array}{l}1.42, \mathrm{~m} \\
1.58, \mathrm{~m}\end{array}$ \\
\hline 8 & 40.3 & - & 35.2 & - & 39.4 & - \\
\hline 9 & 48.1 & $2.01, \mathrm{dd}(9.9,8.8)$ & 55.6 & $1.03, \mathrm{dd}(10.4,4.7)$ & 47.9 & $1.59, \mathrm{dd}(11.5,6.4)$ \\
\hline 10 & 36.6 & - & 36.4 & - & 36.4 & - \\
\hline 11 & 23.6 & $1.92, \mathrm{~m}$ & 22.2 & $1.90, \mathrm{~m}$ & 23.2 & $1.92, \mathrm{~m}$ \\
\hline 12 & 128.2 & $5.63, \mathrm{t}(3.8)$ & 121.1 & 5.37, brd (5.3) & 122.4 & 5.27 , brs \\
\hline 13 & 137.7 & - & 139.9 & - & 143.8 & - \\
\hline 14 & 46.7 & - & 48.2 & $1.93, \mathrm{~m}$ & 41.9 & - \\
\hline 15 & 21.0 & $\begin{array}{l}1.10, \mathrm{dm}(13.9) \\
1.70, \mathrm{td}(13.9,5.2)\end{array}$ & 19.4 & $\begin{array}{l}1.44, \mathrm{tm}(14.2) \\
1.52, \mathrm{dm}(15.0)\end{array}$ & 25.5 & $\begin{array}{l}1.06, \mathrm{dm}(14.0) \\
1.81, \mathrm{~m}\end{array}$ \\
\hline 16 & 21.8 & $\begin{array}{l}1.22, \mathrm{dm}(14.6) \\
1.87, \mathrm{td}(14.6,5.6)\end{array}$ & 23.7 & $\begin{array}{l}1.28, \mathrm{~m} \\
1.85, \mathrm{td}(13.0,4.3)\end{array}$ & 28.5 & $\begin{array}{l}1.33, \mathrm{~m} \\
1.76, \mathrm{~m}\end{array}$ \\
\hline 17 & 36.5 & - & 36.6 & - & 37.2 & - \\
\hline 18 & 40.8 & $2.15, \mathrm{dm}(13.7)$ & 42.2 & $1.99, \mathrm{dm}(13.6)$ & 45.3 & $2.08, \mathrm{dm} 13.7$ \\
\hline 19 & 39.3 & $\begin{array}{l}1.43, \mathrm{dm}(13.7) \\
2.13, \mathrm{t}(13.7)\end{array}$ & 38.9 & $\begin{array}{l}1.20, \mathrm{dm}(13.6) \\
1.56, \mathrm{t}(13.6)\end{array}$ & 46.1 & $\begin{array}{l}0.98, \mathrm{dd}(10.7,2.7) \\
1.77, \mathrm{t}(13.4)\end{array}$ \\
\hline 20 & 42.1 & - & 34.9 & - & 29.9 & - \\
\hline 21 & 28.5 & $\begin{array}{l}1.48, \mathrm{dm}(12.1) \\
1.83, \mathrm{td}(14.6,4.6)\end{array}$ & 28.5 & $\begin{array}{l}1.29, \mathrm{~m} \\
1.45, \mathrm{~m}\end{array}$ & 40.8 & $\begin{array}{l}1.36, \mathrm{dm}(13.3) \\
1.47, \mathrm{~m}\end{array}$ \\
\hline 22 & 29.6 & $\begin{array}{l}1.42, \mathrm{~m} \\
1.63, \mathrm{~m}\end{array}$ & 29.8 & $\begin{array}{l}1.34, \mathrm{dm}(12.8) \\
1.47, \mathrm{tm}(12.8)\end{array}$ & 75.6 & $3.41, \mathrm{dd}(8.8,3.3)$ \\
\hline 23 & 27.1 & $1.09, \mathrm{~s}$ & 27.1 & $1.08, \mathrm{~s}$ & 27.1 & $1.10, \mathrm{~s}$ \\
\hline 24 & 15.6 & $0.88, \mathrm{~s}$ & 15.6 & $0.87, \mathrm{~s}$ & 15.6 & $0.89, \mathrm{~s}$ \\
\hline 25 & 15.2 & $0.98, \mathrm{~s}$ & 15.3 & $0.98, \mathrm{~s}$ & 16.3 & $1.01, \mathrm{~s}$ \\
\hline 26 & 17.2 & $0.98, \mathrm{~s}$ & 14.2 & $0.88, \mathrm{~s}$ & 14.8 & $1.02, \mathrm{~s}$ \\
\hline 27 & 63.3 & $\begin{array}{l}3.56, \mathrm{~d}(11.9) \\
3.82, \mathrm{~d}(11.9)\end{array}$ & - & - & 24.1 & $1.15, \mathrm{~s}$ \\
\hline 28 & 67.8 & $\begin{array}{l}3.24, \mathrm{~d}(10.9) \\
3.57, \mathrm{~d}(10.9)\end{array}$ & 68.2 & $\begin{array}{l}3.16, \mathrm{~d}(11.1) \\
3.50, \mathrm{~d}(11.1)\end{array}$ & 19.0 & $0.86, \mathrm{~s}$ \\
\hline 29 & 181.5 & - & 65.3 & $\begin{array}{l}3.41, \mathrm{~d}(10.9) \\
3.51, \mathrm{~d}(10.9) \\
\end{array}$ & 31.2 & $0.94, \mathrm{~s}$ \\
\hline 30 & 18.4 & $1.24, \mathrm{~s}$ & 26.8 & $0.90, \mathrm{~s}$ & 27.6 & $1.04, \mathrm{~s}$ \\
\hline \multicolumn{2}{|c|}{ Glc (at C-3) } & & & & GlcA (at C-3) & \\
\hline $1^{\prime}$ & 105.4 & $4.34, \mathrm{~d}(7.8)$ & 105.3 & $4.34, \mathrm{~d}(7.9)$ & 104.1 & $4.53, \mathrm{~d}(7.1)$ \\
\hline $2^{\prime}$ & 74.3 & $3.21, \mathrm{dd}(9.2,7.8)$ & 74.3 & $3.21, \mathrm{dd}(8.7,7.9)$ & 76.3 & $3.61, \mathrm{t}(8.2)$ \\
\hline $3^{\prime}$ & 76.9 & $3.36, \mathrm{t}(8.6)$ & 76.9 & $3.35, \mathrm{t}(8.7)$ & 81.2 & $3.58, \mathrm{dd}(9.6,8.2)$ \\
\hline $4^{\prime}$ & 70.3 & $3.31, \mathrm{t}(8.6)$ & 70.3 & $3.31, \mathrm{t}(8.7)$ & 71.7 & $3.56, \mathrm{t}(9.6)$ \\
\hline $5^{\prime}$ & 76.3 & 3.26 , ddd $(8.6,5.3,3.0)$ & 76.2 & $\begin{array}{l}3.26, \text { ddd }(9.4,5.5 \\
2.3)\end{array}$ & 75.2 & $3.78, \mathrm{~m}$ \\
\hline $6^{\prime}$ & 61.4 & $\begin{array}{l}3.68, \text { dd }(11.9,5.3) \\
3.85 \text {, dd }(11.9,2.7) \\
\end{array}$ & 61.4 & $\begin{array}{l}3.68, \text { dd }(11.9,5.5) \\
3.86, \text { dd }(11.9,2.3)\end{array}$ & 169.7 & - \\
\hline & & & & & Gal (at C-3') & \\
\hline $1^{\prime \prime}$ & & & & & 104.7 & $4.57, \mathrm{~d}(7.7)$ \\
\hline $2^{\prime \prime}$ & & & & & 72.6 & $3.62, \mathrm{dd}(9.5,7.7)$ \\
\hline $3^{\prime \prime}$ & & & & & 73.3 & 3.51 , dd $(9.7,3.4)$ \\
\hline $4 "$ & & & & & 68.4 & $3.88, \mathrm{~d}(3.1)$ \\
\hline $5^{\prime \prime}$ & & & & & 75.4 & $3.49, \mathrm{t}(6.6)$ \\
\hline $6^{\prime \prime}$ & & & & & 60.4 & $3.74, \mathrm{dd}(6.2,3.1)$ \\
\hline
\end{tabular}


